\title{
THE UNIVERSITY QUALITY ASSURANCE SYSTEM IN CANADA
}

\author{
T. Bryha ${ }^{1}$ \\ DOI: http://doi.org/10.15350/L_2/2/2
}

\begin{abstract}
The article considers the university quality assurance system in Canada. All postsecondary institutions in Canada have been given the authority to grant academic credentials by their provincial or territorial governments, through charters or legislation that ensures or enables mechanisms for institutional and program quality. Canadian universities share a common culture of quality and excellence, and a commitment to ensuring that high standards are achieved and maintained in their academic programs. Canada's system of university quality assurance is multi-layered, comprehensive and rigorous.
\end{abstract}

Keywords: Canada, university programs, higher education, quality assurance system, academic credentials, educational program.

The term "quality assurance" refers to the achievement of educational program standards set by institutions, professional organizations, government, and/or standard-setting bodies established by government. In Canada, the term "accreditation" refers most often to the evaluation of specific university and college programs by professional bodies and, as such, is an important component of quality assurance. [1]

Canadian universities share a common culture of quality and excellence, and a commitment to ensuring that high standards are achieved and maintained in their academic programs.

Canada's system of university quality assurance is multi-layered, comprehensive and rigorous.

As higher education in Canada falls under the jurisdiction of the country's 10 provinces and three territories, Canadian universities generally receive the authority to grant degrees from provincial legislation (a few universities still retain charters).

Under this authority, each Canadian university is autonomous in academic matters and determines its own quality assurance standards and procedures. These institutional policies and procedures are formal and transparent. They are also coupled with an external review by the relevant provincial quality assurance authorities. For some professional programs, institutional policies and processes also undergo professional accreditation.

In addition, there is a support for a Canadian Degree Qualifications Framework and a commitment to a common framework of quality standards across all

\footnotetext{
${ }^{1}$ Tetiana Bryha, external doctoral candidate, Lviv Polytechnic National University, Ukraine.
} 
Canadian provinces. This means that Canadian universities have a shared understanding of the value of one another's academic credentials and that high quality standards are recognized internationally. [2]

Canadian universities are dedicated to ensuring the quality and continuous improvement of their academic programs in a transparent and accountable manner. This means each institution has developed and maintains periodic internal quality assurance policies and procedures that foster a culture of quality at the university. As responsibility for the quality of Canadian university programs is shared with respective provincial governments, these internal policies take place in the context of external reviews by provincial or regional authorities.

Internal quality assurance policies and procedures vary among institutions, but they largely are focused on academic program reviews that are based on self-evaluation and peer review. These may include:

-A mandatory review of all new and substantially revised programs by the university senate or another university governing body

-Curriculum evaluations

-Periodic self-study reviews

-Student satisfaction surveys

- Peer reviews of programs by external disciplinary experts

The process and quality assessment results are public. [3]

Each Canadian province has its own established system of higher education quality assurance. These systems may be managed by an organization representing universities, an agency or a provincial government. While the approaches differ, provincial quality assurance systems generally review programs to ensure the quality of degrees offered, monitor the frequency and efficacy of institutional reviews, and/or set guidelines to audit existing programs. [4]

In addition to institutional quality assurance processes of the institution, some academic programs in professional fields are subject to accreditation by professional bodies at the provincial, Canadian or international levels (for example, in the fields of nursing, architecture and engineering).

Professional bodies review programs to ensure that the content of university programs, teaching resources and research outputs are of consistently high quality to meet competency expectations and to support future professionals in their area of expertise.

Professional programs at Canadian universities are accredited by specialized bodies. Some programs are also accredited on a voluntary basis (for example, business).

There also exist organizations responsible for the licensing of individual practitioners following graduation from professional programs at Canadian universities. The Canadian Information Centre for International Credentials (CICIC) offers additional information on professional program accreditation and professional licensing. [5]

CICIC is a unit of the Council of Ministers of Education, Canada (CMEC). Founded in 1967, CMEC is the collective voice of Canada's ministers of education. It provides leadership in education at the pan-Canadian and international levels 
and contributes to the exercise of the exclusive jurisdiction of provinces and territories over education.

CICIC was established in 1990, after Canada ratified the UNESCO Convention on the Recognition of Studies, Diplomas and Degrees concerning Higher Education in the States belonging to the Europe Region, to assist Canada in carrying out its obligations under the terms of this convention.

At the request of provincial and territorial governments, Canada became a signatory to the Lisbon Recognition Convention on November 4, 1997, which is an updated version of the 1990 convention.

The convention promotes international mobility by advocating wider recognition of higher-education and professional qualifications.

The Canadian Information Centre for International Credentials (CICIC):

-provides information and referral services to individuals and organizations on the recognition of academic and occupational credentials for working and studying in Canada and abroad;

-provides information on Canada's education systems and quality assurance to assist in the recognition of Canadian qualifications, in collaboration with provincial and territorial ministries of education;

-contributes to policy dialogue and analysis on academic credential assessment issue management in Canada, including building awareness of the impact of developments in related areas such as immigration and labour market policies, and of the need to facilitate mobility by reducing barriers to students and workers moving to, across, or outside Canada;

-develops tools and resources to support the community of academic credential assessors to improve consistency of and capacity for academic credential assessment in Canada;

-manages labour-mobility projects, focusing on academic credential assessment and the teaching profession.

CICIC is Canada's National Information Centre and fulfills Canada's obligations under UNESCO conventions to facilitate the mobility of talent. As such, it is Canada's representative in the ENIC-NARIC Networks, and held the presidency or vice-presidency of the ENIC network from 2004 to 2008 and from 2013 to 2014.

CICIC is an integral part of a growing pan-Canadian and international network of people and organizations concerned with the assessment and recognition of academic and professional qualifications. [6]

All public and private "recognized" and "authorized" postsecondary institutions in Canada have been given the authority to grant academic credentials by their provincial or territorial governments, through charters or legislation that ensures or enables mechanisms for institutional and program quality. "Registered" or "licensed" institutions are monitored by government for institutional and program quality and consumer protection, depending on the jurisdiction. In some jurisdictions, there are processes for program approval or voluntary accreditation for private colleges. Non-registered and non-licensed institutions are private commercial enterprises whose programs are not monitored. [1] 
References

[1] https://www.cicic.ca/1264/An-overview/index.canada

[2] https://www.univcan.ca/universities/quality-assurance/

[3] https://www.univcan.ca/universities/quality-assurance/the-role-of-universities-inquality-assurance/

[4] https://www.univcan.ca/universities/quality-assurance/provincial-quality-assurance-systems/

[5] https://www.univcan.ca/universities/quality-assurance/professional-programs-accreditation/\#B

[6] https://www.cicic.ca/1293/About-the-Canadian-Information-Centre-for-International-Credentials-CICIC/index.canada 